\title{
Investigating the Impact of Public Service Advertising on Blood Donation Intentions under the Influence of Covid-19 Related Moderators
}

\author{
Kamu Spotlarının Kan Bağışı Niyetlerine Etkisinin Covid-19 Moderatörleri Üzerinden \\ İncelenmesi
}

Mehmet Safa Çam, Dr. Öğr. Üyesi, Aksaray Üniversitesi İletişim Fakültesi, E-Posta: msafacam@aksaray.edu.tr

https://doi.org/10.47998/ikad.962176

\begin{abstract}
Keywords:
Public Service

Advertising,

Identification,

Altruism Feelings,

Pandemic Fatigue,

Blood Donation

Intentions.
\end{abstract}

Anahtar Kelimeler:

Kamu Spotu

Reklamları,

Özdeşleşme,

Özgecil Duygular,

Pandemi

Yorgunluğu,

Kan Bağışı Niyeti.

\section{Abstract}

The goal of this research was to explore the role of Public Service Ads (PSAs) on blood donation decisions and the Covid-19 related mechanisms influencing the path to donation behavior. Although blood donation is shown as a form of behavior that is strongly motivated by emotional responses and altruistic behaviors, there are uncertainties in terms of difficulties that the donors experience during the pandemic period. A sample group consisting mostly of young people $(\mathrm{N}=189)$, received a self-administered questionnaire containing questions intended to clarify blood donation drives following exposure to a PSA stimulus. These factors comprised of the components for identification towards PSA characters, empathy, altruistic feelings towards blood donation behavior and donation intentions, and also pandemic related determinants. Regression-based analyzes were used to test the hypotheses, and the effects of Covid-19-derived factors on the blood donation process were investigated through moderator analysis. The results revealed that the empathy and identification levels towards PSA characters vary due to presenting whether the donor-type or the patient-type. No statistically significant results were found between the interactions of the risk of getting infected and altruistic feelings on blood donation intentions. However, it is concluded that pandemic fatigue significantly predicted the relationships between empathetic responses and altruistic feelings.

$\ddot{O} \mathbf{z}$

$\mathrm{Bu}$ araştırmanın amacı, kamu spotu reklamlarının kan bağışı niyetleri üzerindeki rolünü ve bağış tutumlarının oluşumunda mesaj etkinliğini belirlediği düşünülen Covid-19 kaynaklı faktörleri incelemektir. Kan bağışı, duygusal tepkiler ve özgecil davranışlar tarafından güçlü bir şekilde motive edilen bir davranış biçimi olarak gösterilse de pandemi döneminde potansiyel bağışçıların deneyimlediği engeller konusunda belirsizlikler bulunmaktadır. Genç bir katılımcı kitleden oluşan örneklem grubu $(\mathrm{N}=$ 189), kan bağışı davranışıyla ilgili kamu spotu reklam uyaranına maruz kaldıktan sonra bağış motivasyonlarını temsil eden ifadeleri içeren bir anket formunu derecelendirmiştir. Anket formu, kamu spotu reklam karakterlerine yönelik özdeşleşme, empati, kan bağış1 davranışına yönelik özgecil duygular, bağış niyetleri ve ayrıca salgın ile ilgili belirleyicileri ölçmeye dayalı ifadeleri içermektedir. Hipotezleri test etmek için regresyon temelli analizler kullanılmış ve Covid-19 kaynaklı faktörlerin mesaj etkinliği sürecinde kan bağışı niyetlerine ilişkin etkileri moderatör analizleri ile incelenmiştir. Sonuçlar, reklam karakterlerine yönelik empati ve özdeşleşme düzeylerinin, bağışçı ya da hasta tipinin sunumuna göre farklılaştığını ortaya koymuştur. Ayrıca, pandemi yorgunluğunun empati tepkileri ile özgecil duygular arasındaki ilişkileri önemli ölçüde 1lımlaştırdığı sonucuna varılmıştır. Bununla birlikte, enfeksiyon kapma riski ile özgecil duygular etkileşiminin kan bağışı niyetleri üzerinde istatistiksel olarak anlamlı bir etkiye sahip olmadığı sonucuna varılmıştır. 


\section{Introduction}

The vital fluid that human beings need most is blood. Although the demand for this high-priority liquid remains the same during the Covid-19 crisis, an alarming decrease emerged in the number of blood donors and therefore in national blood supplies (Masser et al., Hyde, \& Ferguson, 2020; Miah, 2020). World Health Organization (2020) reported that the Covid-19 pandemic has led to a significant reduction in blood reserves in many countries and negatively influenced blood-related activities. For instance, the daily average test volume performed on blood samples decreased during the Covid-19 crisis, resulting from a $60 \%$ reduction in blood donation numbers per day in Turkey (Özgüven, 2020). The curfews at weekends announced by The Turkish Ministry of Internal Affairs excluded the going-outs for blood donation and immune plasma services during the outbreak of the pandemic. Even so, the regular donations were still below the required five thousand levels to reinforce the existing blood supplies (K1z1lay, 2020). The shortage in blood stocks was immediately tackled by the official authorities and by many of the non-governmental organizations, and communication campaigns have been conducted across the country. Even though ongoing communication efforts through public service ads and printed information, the donation behavior seems to be suppressed by virusbased factors which avoid blood supplies to reach the pre-pandemic levels. This could be crucial in examining blood donation campaigns become incapable against the concerns caused by the Covid-19 outbreak.

Researchers state that health communications campaigns do not always perform better in terms of the desired effects due to experienced conditions (Gill \& Boylan, 2012). This is particularly due to the public's interest in focusing on issues related to their concerns that lead to trivializing all kinds of other matters (Crocker et al., 2017). The Covid-19 disaster may have caused such an underestimation and have deeply affected the blood donation solidarity based on the risk of getting infected. It is possible to state that despite dozens of information conducted through mass communication that the Covid-19 virus is not transmitted by blood; people abstain from donation and demonstrate resistance behaviors towards persuasive messages. Despite the blood donation has been considered such a behavior in line with social consciousness before the pandemic (Raghuwanshi et al., 2016; Steele et al., 2008), we are witnessing a dramatic decline in blood supplies even there are intensive communication efforts during Covid-19 crisis. Therefore, it would not be wrong to express that many aspects of social consciousness, especially the feelings of altruism, are deeply injured, and coping with the fear of the virus has certainly affected people's anxiety and stress levels which may have led to pandemic fatigue.

Studies carried out during the pandemic, generally focus on health behaviors. However, there are very few studies questioning the pandemic effect on blood donation behaviors. To contribute this gap, current paper aims to examine the relationships between communication efforts and donation decisions through a pandemic perspective. In this regard, it will be of great importance to examine the Covid-19 mechanisms that moderate the associations among persuasive efforts promoting blood donation behaviors, altruistic feelings, and donation decisions. Prior to this, the ties between identification with the PSA characters and empathetic responses were investigated under the influence of pandemic 
fatigue moderator which is assumed to affect blood donations during the pandemic crisis. Next, the relationships between altruistic feelings and behavioral intentions were evaluated in light of the effects of experiencing pandemic conditions on perceived vulnerability to disease. To achieve this goal, the moderated moderation analyzes were conducted. The findings are expected to lead to a deeper understanding of the direct and indirect effects of PSAs on blood donation intentions, especially in times of crisis.

\section{Hypothesis Development}

\section{Public Service Advertising and Empathetic Responses}

Public service ads (PSAs) are announcements that are carried out to promote desired outputs in the public interest. PSAs focus on raising awareness and educating the public in achieving desired behaviors on important social issues (Lundgren \& McMakin, 2013). They are widely used in communicating health messages, for instance, to promote blood donation behavior, to raise awareness for seat belts, and to persuade quitting cigarette. According to Bagozzi and Moore (1994), there are two distinct types of PSAs targeting (1) groups of patients in need of help who are vulnerable to health problems and (2) groups of people who intend to help by donating their time or money to a valuable objective. Numerous studies and theories posit that viewers generally engage with characters and develop emotional ties with them (Cohen, 2001; Green et al., 2004; Hoeken \& Sinkeldam, 2014; Moyer-Gusé, 2008) which may be the reason why PSAs are categorized through character-based approach. Considering the characters depicted in the PSAs, it could be assumed that viewers develop an attitude by fostering recognition in line with the patient and the donor features in the ad. For instance, exemplification theory (Zillmann, 1999) suggests that the extent of similarity between the character and the viewer specifies the exemplar as a case in point. Therefore, the individual experiences an empathic arousal letting an attitude formation for the desired effect based on the exemplar depicted in the PSA (Zillmann, 1991, p. 141). Both the perceived similarity and empathy with PSA characters are firmly linked to the concept of identification (Kim et al., 2012). Cohen (2001, p. 247) defines identification as leaving the actual self and "becoming the other that we assume the identity of the target of our identification". Accordingly, character identification enables viewers to perceive that they resemble the character, or feel like the character (Igartua, 2010; Moyer-Gusé, 2008; Murphy et al., 2013). This process modifies current beliefs and attitudes by avoiding counter argumentation and could help to accept the values and beliefs of the characters depicted within the message (Lee et al., 2016). Bearing this in mind, the aforementioned influences could be the key mechanisms that lay behind the persuasive impact of the PSAs.

Following that, whether the extent of identification towards different PSA characters causes a variation in emotional reactions is a notable issue, as well. The distinctive attributes of the character types can be an agent for the beliefs and attitudes of the viewers (Igartua \& Marcos-Ramos, 2015). Theories on reactions to media characters mainly rise to the principal opinion that viewers are faced with the media characters as different social identities (Hefner et al., 2007). According to identification theory (Cohen, 2001), 
an individual visualizes him/herself as others and involve in the character's attribution. In other words, viewers act as the character feels and behaves. Therefore, the PSAs which depict characters invite viewers to develop a mental imagination of the events. Individuals not only comprehend how and why an event occurs, but also engage in mental simulation described as "the cognitive construction of hypothetical scenarios by imagining themselves in the same situation" (Taylor \& Schneider, 1989, p. 175). When individuals simulate events, they repeatedly imagine their self-acts whether actual or potential, and shape behavioral scenarios in which they are the main character (Escalas, 2004). The basic tasks of the characters and the features they reflect are principal components affecting the simulation process. In this case, it can be assumed that the perceived similarity towards donor-centric or patient-centric PSA characters may lead to different empathetic reactions. As stated formally;

H1. The degree of empathetic responses varies towards donor-focus or patientfocus characters in PSAs that promote blood donation behavior.

\section{Altruism Feelings in Blood Donation Behavior}

The persuasion effectiveness of PSAs is largely embodied in the "help-self" focus (Bagozzi \& Moore, 1994). Supporting this notion, studies have been conducted to suggest that blood donation behavior is closely associated with altruistic feelings (Healy, 2000; Lemmens et al., 2009; Murphy \& Mcsweeney, 2009; Steele et al., 2008). Altruism characterizes one's eagerness in helping others without expecting any benefit (Evans \& Ferguson, 2014). Whilst the helping behavior covers the results of an activity, the feeling of altruism deals with the drive behind the act (Dovidio \& Penner, 2003). Since altruistic feelings and behaviors are considered to be "motivated by a genuine desire to benefit another person" (Lay \& Hoppmann, 2015, p. 34), and "a blood donation is a pro-social act which costs to the individual but benefits others" (Wildman \& Hollingsworth, 2009, s. 493), the inducement of blood donation in PSAs is mostly accompanied by "helpself" motivation. This is congruent with the notion depicting that altruistic feelings and behaviors heavily depend on empathetic responses to others (Batson et al., 1995). Back to PSAs, it is assumed that the spokes-characters presented to encourage donation behavior allow the audience to develop emotional ties. Therefore, empathetic responses towards engaging characters in PSAs have been regarded as to be another key incentive in terms of blood donation (Steele et al., 2008). Accordingly, much of the researches underlined that the correlations between empathic responses and altruistic feelings support helping behavior to others which is a feature of pro-social personality (Barreto, 2019; Einolf, 2008; Franzen et al., 2018). Despite empathic concerns involves a principal key factor in benevolence behaviors, in some studies, the associations among altruistic feelings, empathic responses, and blood donations have been reported statistically insignificant (Einolf, 2008; Karacan et al., 2013). This may be due to the results of a field study based on measuring the general empathic abilities of the participants. However, based on the general literature on this theme, it is likely in any PSA message designed in a gain-framing approach, the identification with the characters whether a donor-centric or a patientcentric, can predict the feelings of altruism. Therefore, we think that developing positive emotions in a gain-framing message, specific to a PSA communication that stimulates blood donation behavior, can boost empathetic abilities and therefore altruism feelings. The hypothesis can be expressed as follows. 
H2a. Empathetic reactions to PSA characters positively stimulate altruistic feelings.

H2b. Altruism feelings have positive associations with the intention to donate blood.

\section{Pandemic Fatigue and Perceived Vulnerability as Covid-19 Related Moderators}

An ordinary person could form a desirable attitude towards the PSAs by going through the pathways portrayed above, at a time in which everything goes well without a worldwide deadly crisis. However, humanity is facing a Covid-19 crisis and seems likely to feel the impacts of the pandemic for long, particularly when the mutation threats and the effectiveness of the vaccine set the agenda. Therefore, it is crucial to reconsider the attitudinal processes towards donating under the influence of the pandemic crisis.

The Covid-19 pandemic has had negative effects on people's psychological states. Anxiety and feeling of depression were reported among the primary emotional distress following the emergence of the pandemic (Morgan, 2020). In one of the recent studies, it was found that three-in-five of the people felt anxious or worried due to the outbreak (Biddle et al., 2020). The term "pandemic fatigue" has been offered by World Health Organization (2020) to accent the pervasive sense of anxiety among people against the long-lasting and unpredicted status of the Covid-19 pandemic (Elia \& Vallelonga, 2020). Pandemic fatigue was defined as "demotivation to follow recommended protective behaviors, emerging gradually over time and affected by a number of emotions, experiences, and perceptions" (WHO, 2020, p. 7). Further, pandemic fatigue has been associated with feelings of "hopelessness, alienation, and complacency" towards behavioral intentions in the report (p. 8). Pandemic fatigue may be due to avoiding interacting with people causing them to get weak signals from others in terms of body language, voice, and emotional expressions (Epel \& Fromer, 2020). In line with this, a recent cross-sectional study conducted through a sample of 4,700 subjects in Turkey revealed that nearly $\% 65$ of the population feels psychological fatigue under the isolation measures partly due to avoiding crowded places during the Covid-19 crisis (Morgul et al., 2020). The study stated that emotional fatigue was the result of keeping away populous locations, and of hygiene rules, physical distancing, and social isolation.

Coming back to the report (WHO, 2020), pandemic fatigue has been characterized as not adhering to recommendations and restrictions adequately, a decline in efforts to get accurate information about the pandemic, and underestimating the risks of Covid-19 outbreak. Therefore, when considered as "hopelessness, alienation, and complacency", pandemic fatigue may also lead to a lack of concern about people in need of help and inhibit donating behavior. Accordingly, the current study predicts pandemic fatigue as a barrier on the pathways between empathetic responses and altruistic feelings. Briefly stated, pandemic fatigue moderates the paths to altruistic feelings.

H3. Pandemic fatigue moderates the relationships between empathetic responses towards PSA characters and altruistic feelings.

Apart from that, the risk of getting an illness is considered as one of the factors that hinders the blood donation intention (Giles et al., 2004; Masser et al., 2020; Sojka 
\& Sojka, 2008). Conceptualized as the fear of getting infected, perceived infectability is related to "beliefs about vulnerability to future health problems" (Duncan et al., 2009). Because the concept of risk refers to the probability and severity of negative consequences (Van Der Pligt, 1998), perceived infectability may be a crucial cause of avoiding a riskyseemed donating behavior. Following the Covid-19 pandemic, people have been exposed to alarming mass media news about those infected, which caused them to face the fear of getting the virus, hence, stress and anxiety (Gonzales-Olmo et al., 2020). Thus, people have become more strictly bound to hygiene rules than ever before resulting in acting with the concern of getting infected (Yamada et al., 2020). This may have caused an increase in the existing perceived vulnerability due to the Covid-19 crisis.

Despite isolation and lockdowns can be considered as possible causes of declining blood supplies, it should be stated that fear of getting infected could be the underlying reason that avoids people donating blood. Therefore, it is essential to reconsider the relationships between altruistic feelings and donation intentions under the influence of perceived vulnerability to disease. The current paper also focuses on the moderating effects of perceived vulnerability which has been fueled by the Covid-19 crisis. A recent study found that altruistic feelings are correlated to anxiety and depression development, specifically in a state of perceiving higher risks towards virus (Feng et al., 2020). The study revealed that altruistic individuals with high-risk perceptions experience worse mental health outcomes. Higher levels of anxiety may further increase perceived vulnerability concerns through fear of getting infected. Therefore, it can be assumed that the perceived vulnerability which increased during the pandemic, is the underlying reason why altruistic individuals pause helping others by donating blood. As stated in hypothesis;

H4. The relationships between altruistic feelings and donation intentions are characterized under the influence of perceived vulnerability levels due to experiencing a pandemic.

With this respect, it will be of great importance to examine the mechanisms that moderate the associations between public service ads (PSAs) and blood donation decisions. To achieve this, a single moderation and a moderated moderation models were tested in this study. First, the researcher expected pandemic fatigue to moderate the relationship between empathetic responses and general altruistic feelings. Pandemic fatigue was assumed as a restraint domain surrounding the empathetic reactions induced by character types in PSAs. Viewers are expected to experience altruistic emotions following to simulate engaging characters (whether donor or patient) in PSAs by sharing their beliefs and emotions. However, dependent on the stress, anxiety, and other emotional challenges due to Covid-19, the proneness to donate blood may become worthless. Moreover, the study assumes that fear of getting infected due to the Covid-19 pandemic would alleviate the associations between altruistic feelings and donations intentions. Accordingly, experiencing a pandemic crisis was considered to become a moderator influencing the perceived risk of getting infected. This was because while perceived vulnerability to any sickness can be a general attitude, experiencing a pandemic crisis would likely alter the ways people perceive risks. The research model was illustrated in Figure 1. 


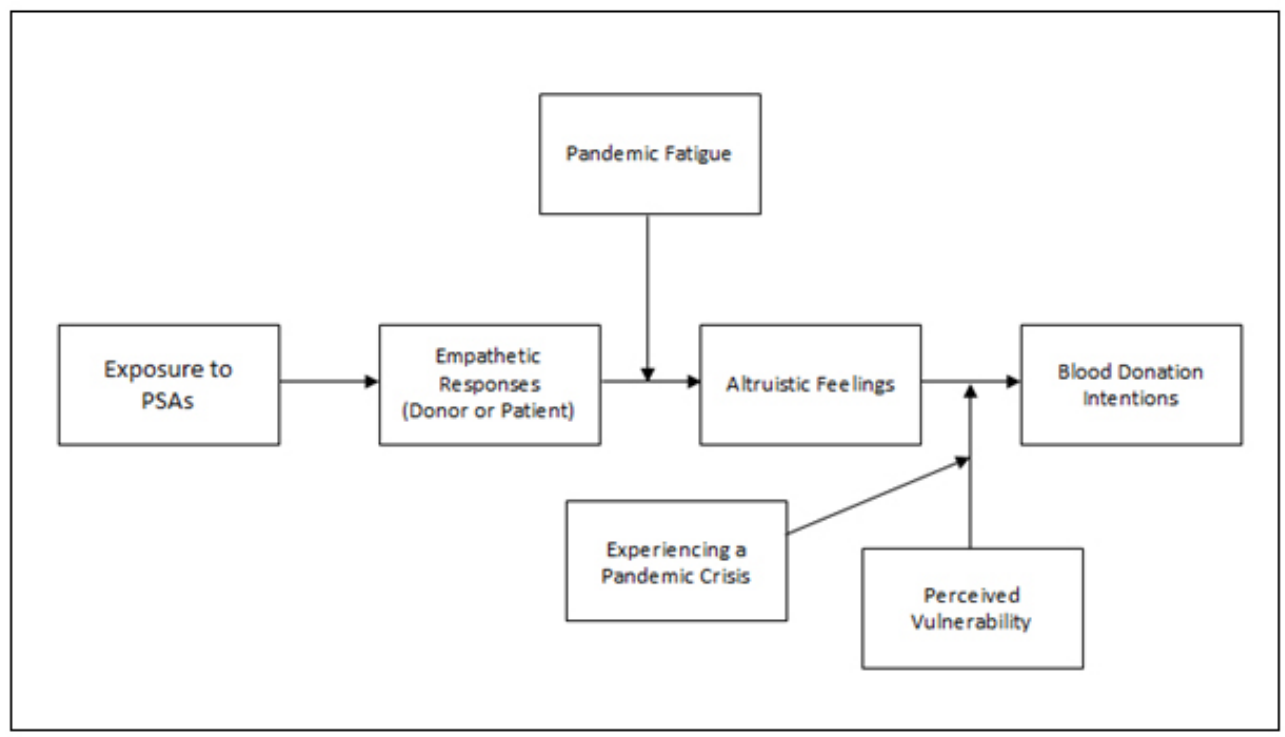

Figure 1. The Research Model

\section{Research Methodology}

This empirical study was conducted at Aksaray University by utilizing an online questionnaire, between December 20, 2020, and February 15, 2021. The study has been conducted throughout lockdowns for all levels of education and partial curfews on weekends and specific hours. The data was gathered through a simple cluster sampling. University students from Aksaray University participated in an online survey and requested to fill the questionnaire during the restrictions and outside of distance education class hours. Contributors were told that participation was completely voluntary basis and no extra credit would be available. This research was conducted with the permission and ethical approval by the Aksaray University Human Researches Ethics Committee issued $12 / 2020$. All subjects have stated their consent by explicitly approving to participate in the study following official information about the aims, safety, and retention of data and contacts for any further questions related to the survey.

\section{Participants and Procedure}

A total of one hundred and ninety-five students from Aksaray University were recruited to participate in this research. One hundred and eighty-nine of those rated the survey items correctly and completely. The sample consisted of 59 male (31\%) and 130 female $(69 \%)$ with the mean age $20.73(\mathrm{sd}=0.46)$. The majority were undergraduate students $(65 \%)$ and the rest were associate degree students $(35 \%)$. In this experimental study, all participants were randomly recruited into three different groups to view one of the PSAs (donor-focus $n=61$, patient-focus $n=80$, none $n=48$ ) promoting blood donation behaviors. Before being exposed to ad stimulus, all subjects rated questionnaire items regarding demographic information, general health behavior attitudes, blood donation attitudes, pandemic fatigue, and whether they donated blood in the Covid-19 crisis. 
Following this procedure, each group was exposed to one of the PSA stimuli and responded to questions regarding manipulation statements, empathic responses, blood donation intentions, and PSA message attitude. In selecting stimulus materials, a group of PSAs was evaluated by two academicians who have expertise on the effectiveness of public service ads. The coders examined the stimuli within the focus of the emotional intensity and empathic potential of the PSA characters. The control group stimulus, which included statistics and a didactic approach about blood donation, covered no engaging character representation.

\section{Measures}

The present research used a questionnaire that incorporated various items from scales in prior studies to measure empathetic responses, altruistic feelings, pandemic fatigue, and perceived vulnerability to disease. Participants rated the items on a 5-point Likert type scale except for those measuring the demographic attributes, donation status in the pandemic, and whether they think to donate in the pandemic.

Five items were selected from the Basic Empathy Scale-BES (Jolliffe \& Farrington, 2006) to measure individuals' status for identifying with the characters. The item statements were adapted to measure viewers' reactions to the characters due to PSA exposure, such as "The character's emotions affected me much", "I got caught up in character's feelings easily" and "I could understand the character emotionally when I viewed him on TV". The reliability coefficient for this scale was 0.914 .

Altruism feelings were assessed by using the Self Report Altruism Scale-SRAS (Rushton et al., 1981). Ten of the 20 items from the SRA scale were selected which seemed relevant to the behavior promoted in the PSA. Participants were asked to rate the frequency of their engagements in such behavior as donating blood or in charity activities (e.g. "Donating goods or clothes to a charity", "donating blood", "working as a volunteer for a charity", "offering to help a handicapped or elderly stranger across a street"). Higher average mean scores represented greater altruism feelings. The Cronbach's $\alpha$ for the scale was 0.942 .

The emotional fatigue experienced by the individuals was evaluated by using the Pandemic Fatigue Scale (PFS) which was recently produced by Lilleholt, Zettler, Betsch, and Böhm (2020). The six-item scale consists of two sub-scales measuring Information Fatigue (IF) and Behavioral Fatigue (BF). Subjects rated the frequency with which they felt like being exhausted and tired when they encounter any arguments or situations related to Covid-19. (e.g. "I try to watch all the Covid-19 discussions in TV shows, newspapers and radio programs, etc.", "I feel calm following all of the behavioral regulations and recommendations around Covid-19"). The reliability coefficient of the scale calculated in this study was $\alpha=0.77$.

Perceived Vulnerability to a Disease scale - PVDS (Duncan et al., 2009) was used to assess the fear of getting infected from a disease. The sub-scale of PVDS directly measures the perceived infectability which means beliefs about vulnerability to future health problems. The scale consists of six items and Cronbach's $\alpha$ for the scale was 0.753 .

Intentions for donating blood were evaluated using a scale consisting of four 
statements. (e.g. I have intended to give blood in the next months"). The reliability coefficient of the scale was determined as 0.88 . In addition to measuring the general tendencies of the participants as explained above, they were asked questions about how many times they donated before, whether they donated in the pandemic, and whether they considered donating in the pandemic. Accordingly, respondents were asked "How many times have you given blood before?", "Have donated in the Covid-19 pandemic?", and "Would you like to donate blood during the pandemic period?" The last question was used in the analysis as a moderator of the perceived vulnerability scale. Answers to these questions were given categorically.

\section{Analytical Methods}

This study started with CFA analysis to test the construct validity. The goodness of fit indices of CFA and factor loadings was used to assess the validity of the instruments. Next, a series of one-way ANOVA analysis was conducted to examine the significant differences between each dependent variables (empathy to characters, altruistic feelings, intention to donate, pandemic fatigue, and perceived vulnerability) and categorical variables such as identification type, gender, education, donation status in pandemic and willingness to donate in the pandemic. After specifying the significant differences between variables, single moderation and moderated moderation analyses were performed to test the regulatory effects of pandemic fatigue and perceived vulnerability on the paths to donation intentions. Both of these regression-based models were run with SPSS macro software called PROCESS (Hayes et al., 2017) which is available online. Therefore, to test the single moderation and interactive moderation effect, we used Model-1 and Model-3 respectively. The bootstrapping procedure which is a basic logic behind the PROCESS analysis offers that the significance of the paths is due to the CI intervals crossing over the zero point (Hayes et al., 2017). To test the assumptions, lower and upper levels of CI (LLCI-ULCI) values were checked. The values going from negative to negative or from positive to positive, but not from negative to positive or vice versa, indicate that the result is significant. The PROCESS models were performed within the $95 \%$ confidence interval by using 5,000 bootstrap samples.

\section{Results}

Before the analysis testing the causalities, a confirmatory factor analysis (CFA) was conducted to validate how well the research instruments obtained from the literature represent the relevant structures. A first-order CFA initially reported a poor fit for the model necessitating examining the standardized coefficients weights for each item and modification alternatives. Thus, three of the Perceived Vulnerability scale items were decided to extract from the analysis because of the low factor weights than suggested. It is recommended that one single item should have at least 0.60 -factor weights for acceptable construct validity (Hair et al., 1999). Following the revised CFA, the model fit indices were calculated at an acceptable level. In particular, goodness-of-fit indices for the revised CFA model indicated an adequate fitting for the data meaning that the variables were well represented by the items responded by the subjects $\left(\chi^{2}=374.03, \mathrm{df}=124, \chi^{2} / \mathrm{df}=3.01\right.$, $\mathrm{CFI}=0.95, \mathrm{TLI}=0.94, \mathrm{GFI}=0.90, \mathrm{AGFI}=0.86, \mathrm{RMSEA}=0.07)$. 
Reliabilities of the measurement items were evaluated with Cronbach's $\alpha$, factor weights, composite reliabilities, and average variance extracted estimations. The factor weights between 0.60 and 0.94 showed that the remaining items were above the recommended threshold. In all constructs, Cronbach's $\alpha$ exceeded the baseline of 0.70 (Santos, 1999). CR values varying between 0.83 and 0.95 also exceeded the lower limit of 0.70 . Also, AVE rates were between 0.61 and 0.85 , exceeding the baseline limit of 0.50 (Fornell \& Larcker, 1981). The key measures for construct reliability and validity of research instruments used in the current paper are shown in Table 1.

Table 1. CFA Results of Construct Reliability and Validity

\begin{tabular}{|c|c|c|c|c|c|}
\hline Constructs & Items & Loading & $\alpha$ & $\mathbf{C R}$ & AVE \\
\hline \multirow{5}{*}{ BES } & The character's emotions affected me much & 0.81 & \multirow{5}{*}{0.91} & \multirow{5}{*}{0.89} & \multirow{5}{*}{0.73} \\
\hline & I got caught up in the character's feelings easily & 0.88 & & & \\
\hline & I could understand the character emotionally when I viewed him on TV & 0.87 & & & \\
\hline & I could get swept up in character's feelings & 0.73 & & & \\
\hline & I was aware of the character's feelings. & 0.82 & & & \\
\hline \multirow{10}{*}{ SRAS } & Donating goods or clothes to a charity & 0.78 & \multirow{10}{*}{0.94} & \multirow{10}{*}{0.95} & \multirow{10}{*}{0.85} \\
\hline & Donating blood & 0.84 & & & \\
\hline & Working as a volunteer for a charity & 0.82 & & & \\
\hline & Offering to help a handicapped or elderly stranger across a street & 0.85 & & & \\
\hline & Giving directions to a stranger & 0.73 & & & \\
\hline & Giving money to a charity & 0.77 & & & \\
\hline & Letting someone I didn't know too well borrow an item of some value to me & 0.82 & & & \\
\hline & Helping a classmate I did not know well with a homework & 0.81 & & & \\
\hline & Offering to help a handicapped or elderly stranger & 0.75 & & & \\
\hline & Offering the seat on a bus to a stranger or elderly person & 0.76 & & & \\
\hline \multirow{5}{*}{ PFS } & $\begin{array}{l}\text { I try to watch all the Covid-19 discussions in TV shows, newspapers and } \\
\text { radio programs, etc. }\end{array}$ & 0.60 & \multirow{5}{*}{0.77} & \multirow{5}{*}{0.83} & \multirow{5}{*}{0.61} \\
\hline & $\begin{array}{l}\text { I feel calm following all of the behavioral regulations and recommendations } \\
\text { around Covid-19 }\end{array}$ & 0.71 & & & \\
\hline & I am comfortable hearing about Covid-19 & 0.73 & & & \\
\hline & I am having my spirit fight against Covid-19 & 0.60 & & & \\
\hline & $\begin{array}{l}\text { When friends or family members talk about Covid-19, I try to involve in } \\
\text { the subject }\end{array}$ & 0.72 & & & \\
\hline \multirow{3}{*}{ PVDS } & I prefer to wash my hands pretty soon after shaking someone's hand & 0.77 & \multirow{3}{*}{0.75} & \multirow{3}{*}{0.88} & \multirow{3}{*}{0.71} \\
\hline & $\begin{array}{l}\text { I dislike wearing used clothes because you do not know what the last per- } \\
\text { son who wore them was like. }\end{array}$ & 0.94 & & & \\
\hline & I am uncomfortable sharing a water bottle with a friend & 0.80 & & & \\
\hline \multirow{4}{*}{ DDS } & I have intended to give blood in the next months & 0.76 & \multirow{4}{*}{0.88} & \multirow{4}{*}{0.91} & \multirow{4}{*}{0.78} \\
\hline & I am thinking of donating blood in the near future & 0.90 & & & \\
\hline & $\begin{array}{l}\text { If there were a blood donation organization on campus I would love to } \\
\text { donate }\end{array}$ & 0.85 & & & \\
\hline & I'll attempt to donate blood & 0.84 & & & \\
\hline
\end{tabular}


Table 2 indicates mean differences across groups on empathetical concern, altruism feelings, pandemic fatigue, perceived infectability, and blood donation intention scores. Donor-centric and patient-centric viewers reported similar levels of BES, but participants who viewed PSA with no-dominant-character reported higher empathetic responses than those groups $(\mathrm{p}=0.00)$. Identification type group also reported differences significantly in PFS ( $p=0.02)$, slightly higher scores for no-dominant-character group and in PVDS, higher scores for donor-centric group $(p=0.00)$. In the focus of these results, the H1 hypothesis that assumes patient-centered and donor-centered character types were associated with different levels of empathy was approved.

Table 2. ANOVA Statistics for the Variables

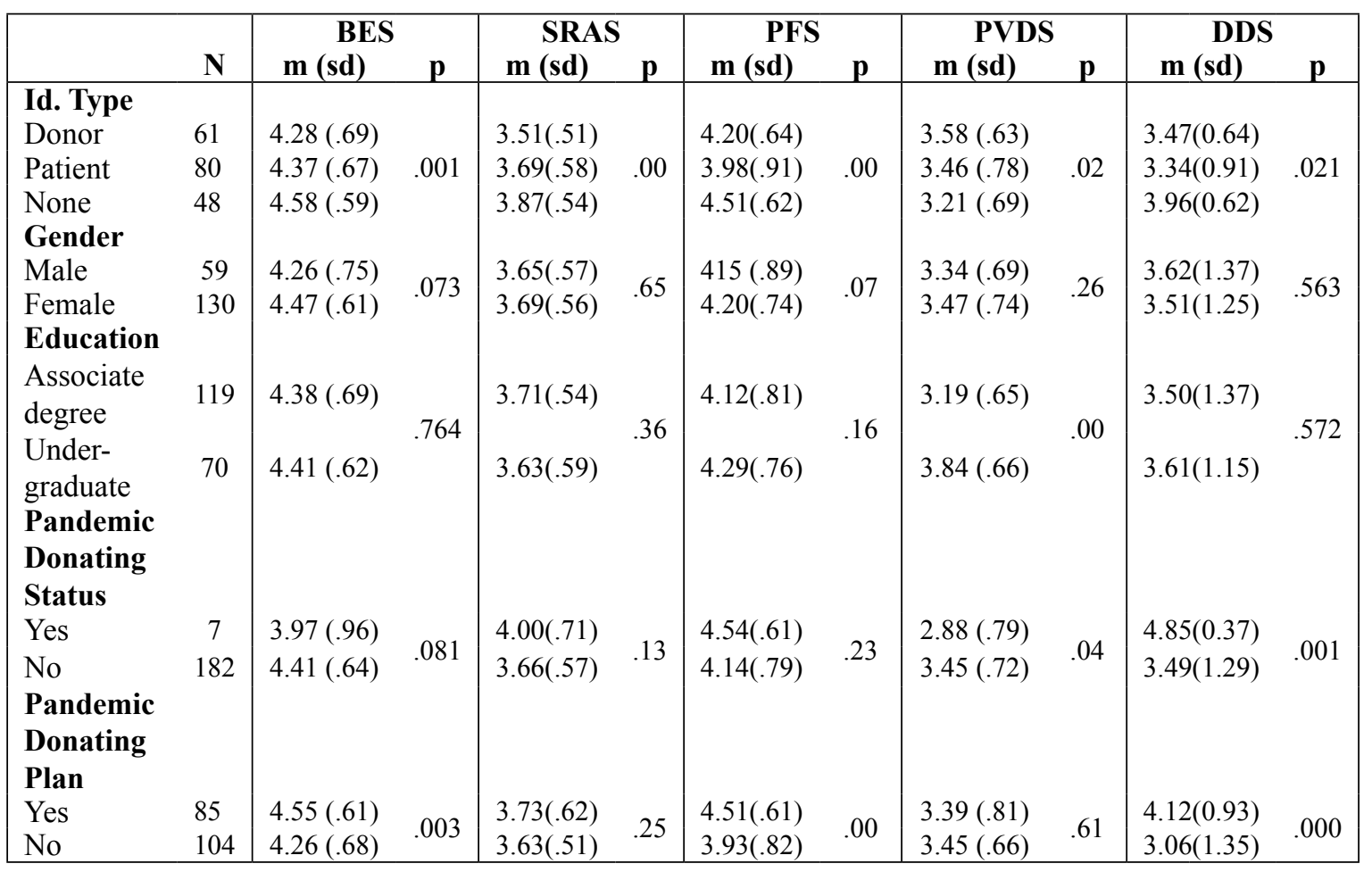

Total N = 189 Id. Type, identification type; BES, Basic Empathy Scale; SRAS, Self-Report Altruism Scale, PFS, Pandemic Fatigue Scale; PVDS, Perceived Vulnerability to a Disease; DDS, Donation Decision Scale.

According to ANOVA results, the gender variables were insignificantly related to all dependent variables except for the Basic Empathy Scale $(p<0.001)$. Also, the highest mean difference in gender groups was found in empathic responses toward character types. In detail, females had higher means in their BES scores than males (mfemale $=4.20>3.83, \mathrm{p}=.000$ ). Similarly, significant differences were found in education and pandemic-donation-status groups in terms of BES scores. The undergraduate students had higher BES mean scores, as in PVDS, than associate degree students. Although the fear of getting infected resulted in lower scores for donation intentions (DDS), this was not a significant result $(\mathrm{p}=0.49)$. The participants who did not donate in the Covid-19 pandemic have higher mean scores in PVDS as expected $(\mathrm{p}=.000)$, despite oppositely occurred in DDS, it was insignificant $(\mathrm{p}=0.41)$. Also, non-donors in the pandemic had 
dramatically higher mean scores in BES than those who did donate. Finally, albeit the average scores of all dependent measures for those who were willing to donate in the pandemic were lower than those who did not have such a plan, the results were not at any significance level $(\mathrm{p}>$.000).

Simple linear regression analysis was used to test the $\mathrm{H} 2$ hypotheses, which suggest that viewers' empathetic responses trigger altruistic feelings and those feelings have causal relationships with intentions to donate blood. The regression analysis revealed that the empathetic reactions that come out due to identification with PSA characters were a significant predictor for altruism feelings, $\mathrm{R}=0.533, \mathrm{R}^{2}=0.284, \mathrm{~F}(1,187)=74.258$, $\mathrm{p}<0.001$. Depending on this finding, it is fairly to state that the H2a hypothesis is accepted. Also, a statistical significance in causal relationships between altruistic feelings and blood donation intentions were significant which means approval for $\mathrm{H} 2 \mathrm{~b}, \mathrm{R}=0.768, \mathrm{R}^{2}=0.590$, $F(1,187)=269.008, p<0.001$. See Table 3 for the regression findings.

Table 3. The Effects of the Main Predictors on Dependent Variables

\begin{tabular}{lcccccc}
\hline Predictor $\rightarrow$ Dependent Variable & B & SE & $\boldsymbol{\beta}$ & t & p & Results \\
\hline & & & & & & $\mathrm{R}=0.533$ \\
Empathetic Responses $\rightarrow$ Altruistic Feelings & 0.355 & 0.173 & 0.533 & 8.617 & 0.000 & $\begin{array}{l}\mathrm{R}^{2}=0.284 \\
\mathrm{~F}=74.258 \\
\mathrm{p}<0.001\end{array}$ \\
& & & & & & \\
& & & & & & $\mathrm{R}=0.768$ \\
Altruistic Feelings $\rightarrow$ Donation Intentions & 0.593 & 0.036 & 0.768 & 16.401 & 0.000 & $\begin{array}{l}\mathrm{R}^{2}=0.590 \\
\mathrm{~F}=269.008 \\
\end{array}$ \\
& & & & & & $\mathrm{p}<0.001$ \\
\hline
\end{tabular}

Multiple regression model in PROCESS macro (Model-1) was used to predict altruism feelings with the interactions between pandemic fatigue and empathetic responses. The research model explained the total variance to a significant extent $\left(\mathrm{R}^{2}=0.679, \mathrm{~F}(3,185)=130.751, \mathrm{p}=.000\right)$. The two-way interaction between BES and PFS showed statistical significance $\left(\mathrm{R}^{2}=0.015, \mathrm{~F}(3,85)=9.013, \mathrm{p}=0.031\right)$. We investigated the current two-way interaction to realize the links between the variables. Table 4 and Figure 2 demonstrate the PFS and BES interaction over altruistic feelings. Interaction paths proposed that pandemic fatigue has a significant effect on BES and moderates the links between BES and SRAS (LLCI $=0.694$, ULCI $=0.3355, \mathrm{p}=0.003$ ). No significant direct effect of PFS on SRAS was detected ( $p=0.723$, LLCI $=-0.4698, \mathrm{ULCI}=0.6756)$. In particular, the findings offer that tolerable and high levels of pandemic fatigue moderates the paths from empathetic responses towards altruistic feelings. High pandemic fatigue represented by the blue color and number 5.00 in Figure 2 significantly moderated the relationships between BES and SRAS ( $\mathrm{t}=3.464, \mathrm{p}=0.007$, LLCI-ULCI=0.164-0.600). Along the same lines, modest levels of pandemic fatigue represented by number 4.40 and red color has also significant effect $(\mathrm{p}=0.002)$. However, the moderation effect of lower levels of PFS was statistically insignificant $(\mathrm{p}=0.475, \mathrm{LLCI}=-0.1029, \mathrm{ULCI}=0.2198)$. Nevertheless, the moderation effect of pandemic fatigue is statistically significant (tInt_1=3.002, p=0.003). Hence, the H3 hypothesis was supported. 
Table 4. The Impact of Pandemic Fatigue as Moderating Variable

\begin{tabular}{lcccccc}
\hline & coeff & se & $\mathbf{t}$ & $\mathbf{p}$ & LLCI & ULCI \\
\hline constant & 2.6182 & 1.0952 & 2.3905 & .0178 & .4574 & 4.7790 \\
BES & -.6298 & .2689 & -2.3421 & .0202 & -1.1604 & -.0993 \\
PFS & .1029 & .2903 & .3545 & .7234 & -.4698 & .6756 \\
Int_1 & .2024 & .0674 & 3.0022 & .0031 & .0694 & .3355 \\
\hline Conditional effects of PFS & & & & & \\
\hline $\mathbf{3 . 4 0 0 0}$ & .0584 & .0818 & .7145 & .4758 & -.1029 & .2198 \\
$\mathbf{4 . 4 0 0 0}$ & .2609 & .0860 & 3.0343 & .0028 & .0913 & .4305 \\
$\mathbf{5 . 0 0 0 0}$ & .3823 & .1104 & 3.4646 & .0007 & .1646 & .6001 \\
\hline
\end{tabular}

Dependent Variable: Altruism Feelings

BES-Basic Empathy Scale, PFS-Pandemic Fatigue Scale

Int_1-The Moderating Path

3.40-Lower PFS, 4.40-Tolerable PFS, 5.00-Higher PFS

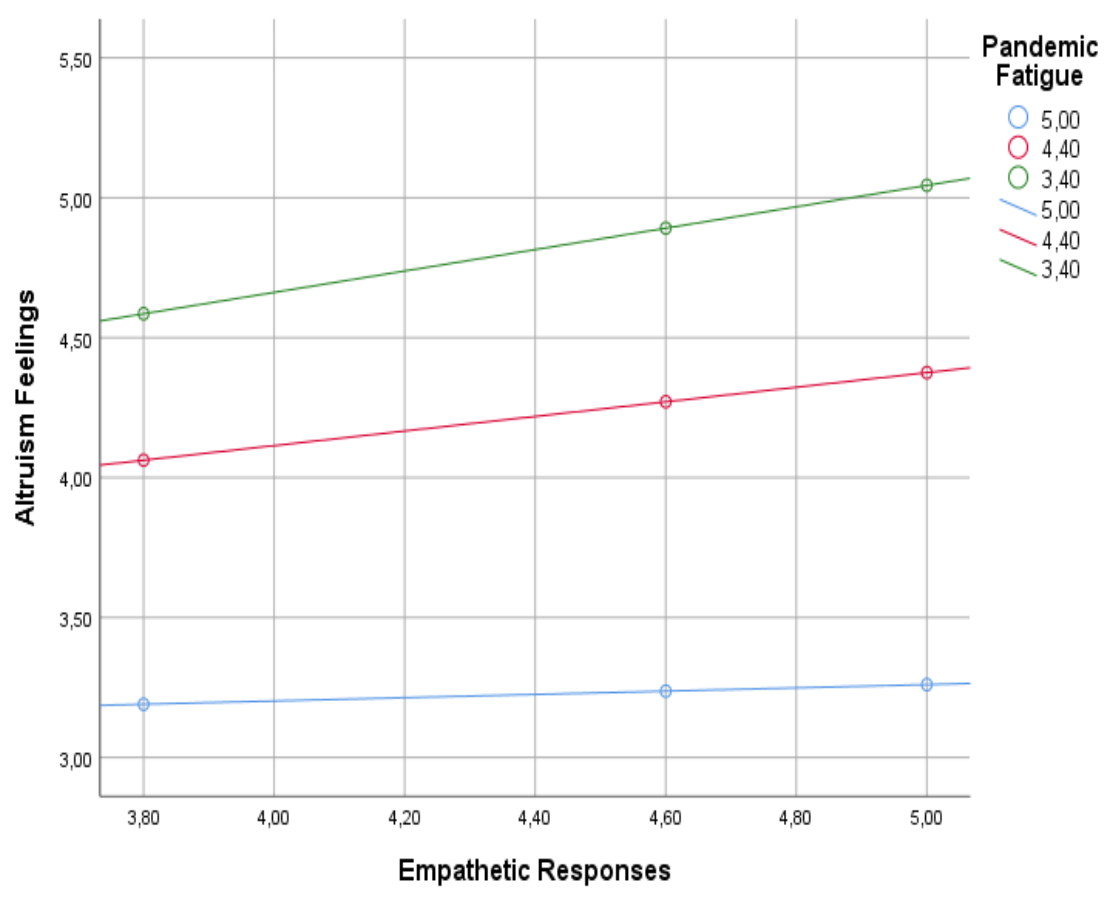

Figure 2. The Relationships between BES and SRAS under the Influence of PFS.

Additionally, Model-3 was conducted to test the H4 hypothesis, which suggests that the effect of altruistic feelings on blood donation intentions varies under the interaction of pandemic and fear of getting infected (see Figure 3 and Table 5). Multiple regression was conducted to predict donation intentions through perceived vulnerability, experiencing a pandemic, altruistic feelings, and the interactions among these three variables assigned as predictors. Although the model summary indicated a high degree of variance explanation strength $\left(\mathrm{R}^{2}=0.617, \mathrm{~F}(7,181)=41.696, \mathrm{p}=0.000\right)$, the three-way interaction did not have a statistical significance (tInt $3=0.526, p=0.599$ LLCI $=-0.311-$ ULCI $=0.538$ ). Thus, the 
H4 hypothesis was not supported. Yet, by examining the interactions in Figure 3, the effects of fear of getting infected on donation intentions during the pandemic period may be comprehended.

Investigating interactions revealed that altruistic feelings affect donating intentions regardless of experiencing a pandemic. Altruism feelings also predicted donation intentions regardless of perceived levels of vulnerability within two pandemic conditions. However, the higher levels of perceived vulnerability during the pandemic period cause a slight decrease in donation intentions. In the non-pandemic period, the perceived vulnerability does not affect different levels but leaves its role to altruistic feelings. It should be noted that these scenarios did not exist at a statistical significance level $(\mathrm{p}>0.005)$ (see Table 5).

Table 5. The Results of Interactions among SRAS, PVS and Pandemic Period

\begin{tabular}{|c|c|c|c|c|c|c|}
\hline Variables & coeff & se & $\mathbf{t}$ & $\mathbf{p}$ & LLCI & ULCI \\
\hline constant & $-2,7482$ & 5,9145 &,- 4647 & 6427 & $-14,4184$ & 8,9219 \\
\hline SRAS & 1,9614 & 1,3163 & 1,4901 & ,1379 &,- 6358 & 4,5586 \\
\hline PVS & ,9123 & 1,6553 &, 5512 & ,5822 & $-2,3538$ & 4,1784 \\
\hline Pandemic Period &, 5827 & 3,3078 & , 1762 &, 8604 & $-5,9441$ & 7,1095 \\
\hline SRAS x PVS $\rightarrow$ Donation Intentions &,- 3103 & ,3719 &,- 8346 & ,4051 & $-1,0441$ & ,4234 \\
\hline SRAS x Pandemic Period $\rightarrow$ Donation Intentions &,- 3809 &, 7538 &,- 5053 & ,6139 & $-1,8682$ & 1,1064 \\
\hline PVS x Pandemic Period $\rightarrow$ Donation Intentions &,- 2722 & ,9394 &,- 2897 &, 7724 & $-2,1257$ & 1,5814 \\
\hline SRAS x PVS x Pandemic Period $\rightarrow$ Donation Int. &, 1135 &, 2155 &, 5266 & ,5991 &,- 3117 & ,5386 \\
\hline
\end{tabular}

Dependent Variable: Donation Intentions.

SRAS-Self Report Altruism Scale, $P V S$-Perceived Vulnerability Scale

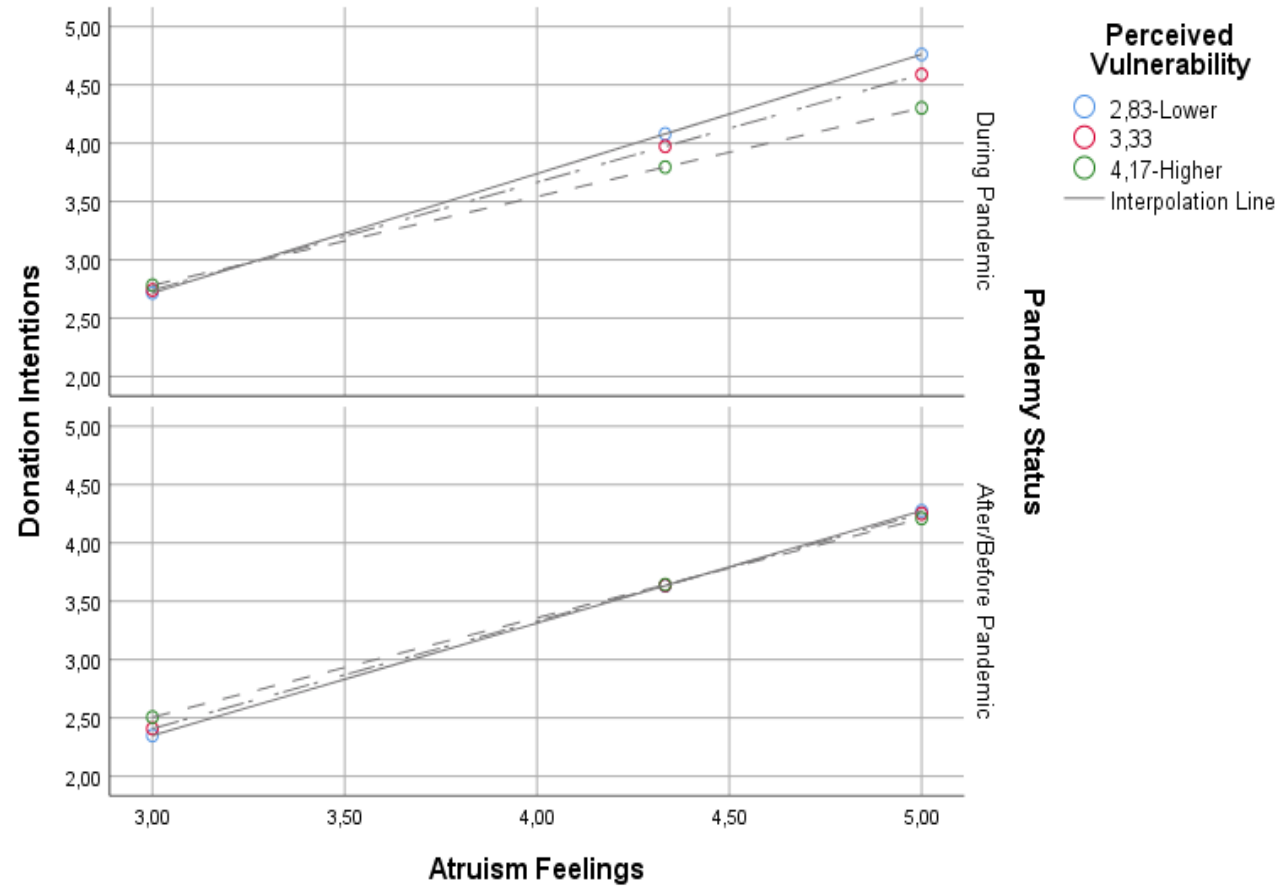

Figure 3. Donation intentions under the influence of PVS, SRAS, and Pandemic Period interactions 


\section{Conclusion}

The demand for blood has risen dramatically under today's pandemic conditions. People have many concerns apart from the others' health conditions during crisis periods, even there are intense efforts as sending effective messages by the authorities and communicators to promote blood donation behavior. However, despite these efforts, the lack of enthusiasm of the population to support blood supplies seems remarkable. It is probably because pandemic-related factors have such impacts suppressing pre-pandemic awareness levels like altruism and interdependence feelings. Very little research has been conducted on the restrictive factors associated with donation behaviors in times of crisis such as the Covid-19 pandemic. However, there is an emerging sensitivity relating to the present status of blood donation behavior and the requirement to study on new motivations during the pandemic period. In one of the recent studies, Masser and colleagues (2020) listed the predictors that regulate blood donation attitudes during the pandemic period. Within this study, the authors made inferences regarding blood donation status by associating predictors such as risk, anxiety, coping appraisal, threat perception, and subjective norm with Covid-19. However, the extent to which pandemic factors affected emotional attributes and altruistic feelings, which are considered to be predictors of donation attitudes, and the effectiveness of PSAs as message drives for blood donation are among the questions that have remained unanswered.

The present article started with a focus on public service advertising (PSA) by considering it as a very high persuasive effort in public health issues. Drawing on the findings of prior studies on the effectiveness of PSAs in promoting blood donation behavior (Beerli-Palacio \& Martín-Santana, 2015; Harrington et al., 2007; MartínSantana et al., 2018), the current research investigates how empathetical reactions towards PSA characters affect altruistic feelings and donation intentions under the influence of the Covid-19 pandemic. The research model suggested that empathetic responses and altruistic feelings as the direct effects of viewing a blood donation PSA are the main motives towards donation intentions. The model also considered the pandemic fatigue and fear of getting infected in an outbreak as Covid-19 related moderators. The role of these predictors on blood donation intentions was examined through an empirical viewpoint.

The findings of this research revealed that, under normal circumstances, PSA exposure feeds empathy towards characters (no matter how they were characterized, donor or patient), while also raising their blood donation intentions through altruistic feelings. The regression-based paths in the basic model match the results supported by prior studies. For example, the existing data provided evidence that altruistic feelings may serve as an influential overpass between empathic responses and donation intentions (Harrington, et al., 2007; Sojka \& Sojka, 2008; Steele, et al., 2008). Therefore; the empathy, altruistic feelings, and donation intention variables - combined for the current study - significantly increase the ability to explain actual donor behaviors. Furthermore, the data tell that blood donation behavior is greatly influenced by emotional predictors. Although the rational process has not been tested in the present study, this finding makes an important contribution to previous studies (Masser et al., 2020) associating donation behavior with rational decision-making processes. While blood donation intentions for 
these individuals are presumably created by internal drives, the PSA with engaging characters as an external source also pioneered the sense of liability towards blood donation intentions. At this point, empathy and altruistic feelings, both key driving forces promoted by PSA, seem to have strongly influenced donors' beliefs and attitudes towards behavioral intentions. However, this result may not be surprising for PSA communications in terms of activating empathy potential through character involvement. Albeit the PSA activity, through which the viewers are evoked to a relational experience over character engagement, has been suggested in many studies (Igartua, 2010; Moyer-Gusé, 2008; Neil et al., 2019), the current paper could be deemed considerable in terms of associating character identification with altruistic behaviors and donation intentions.

In the second part of the study, we tested the moderation effects of Covid-19 predictors. The findings revealed that pandemic fatigue, which was announced to cause apathy in protective measures, negatively affected the relationships between empathy and altruistic feelings towards donation behaviors. Defined as "complacency, alienation, and hopelessness" in seeking Covid-19 related information and as lack of interest towards outbreak measures by the World Health Organization (2020), the pandemic fatigue phenomenon seemingly has adverse impacts not only on precautions but also on goodwill for donation decisions. The state of psychological exhaustion, which is conceptualized originally as emotional fatigue (Maslach, 1982; Wright \& Cropanzano, 1998) in the literature but nowadays comes into social lives in the form of pandemic fatigue, has been reported with negative consequences on the individual's self attributes in several studies (Cropanzano et al., 1996). This may be due to the fact that fatigue is mostly a psychologically-based "state of feeling burnout and overwhelmed" (Barnes \& Dyne, 2009). Fatigue comes in view of a typical feature representing a symptom of a hidden emotional concern. Recent research by Morgul et al. (2020) reported that fatigued individuals showed less positive attitudes towards the precautions taken by the authorities and that they believed less in getting back the control of the Covid-19 pandemic. This kind of arousal may have forced individuals to withdraw from being a part of social issues. Although present findings support this abandonment, it would be a simplistic attempt to assume that the state of mental collapse undermines the PSA effectiveness towards donation attitudes. Indeed, fatigue hinders primary human attributes and perspectives such as altruistic feelings, empathy, and other mutually emotional ties (Kinnick et al., 1996). PSA, as a persuasive incentive, may not be capable of restoring emotional recession in such a crisis as the Covid-19 period when anxiety and stress are experienced at a high level. Nevertheless, the fact that pandemic fatigue is a determinant on the PSA effectiveness could suggest the significance of this paper.

The research model also suggested that the levels of perceived vulnerability that interacted with altruistic feelings in a crisis period would have negative influences on behavioral intentions. Although a statistical significance is not achieved, appreciable findings have the potential to present a clear understanding of how Covid-19 related predictors affect the behavioral outputs. Individuals with higher levels of fear of infection reported lower enthusiasm towards donation intentions during the pandemic period. However, the results revealed that any levels of the contagion risk were not determinative on behavioral intentions when there is no stress-making crisis period. In both cases, 
altruistic feelings should be deemed as the key predictor for donation intentions, in that, higher levels of altruism feelings reflected higher scores for the behavioral intentions. This finding can provide a convincing rationale why individuals refrain from donating during the Covid-19 pandemic and why they donate during a non-crisis period. Findings also support this common belief presented in prior studies (Leung \& Lee, 2020; Masser et al., 2020). However, the nonsignificant statistics of assessments on the risk of infection may suggest that deterring blood donation behaviors cannot be predicted with a mere fear during the pandemic period. For instance, Clowes and Masser (2012) come up with the concept of self-efficacy to explain the individual's pullback from behaviors such as philanthropy and donation, particularly when stress and anxiety deplete individuals emotionally. As an individual capability belief for donation, self-efficacy is the key insight behind the existing certain behaviors within the focal point of emotional responses and existential purposes (Bandura, 2010; Maddux \& Gosselin, 2012). In this case, change or persistence in behaviors is determined through "self-efficacy" which refers to the belief and expectation of coping with fearful situations successfully. Further, the fact that self-efficacy reveals the potential of an individual to exhibit a behavior depends on identification with certain characters and his ability to feed on emotional reactions such as empathy to others (Bandura, 1977). This can be crucial to comprehend that blood donation intentions are most likely driven by an emotional decision-making mechanism. Therefore, this inference requires reimagining the PSA activity. PSAs build behavioral attitudes by applying various emotional appeals, especially fear-driven and patient-based empathy through identification towards the characters. These may also be replaced by an empathic response driven by a donor-based incentive. Hence, PSA can also turn into an ideal instrument for self-efficacy fulfillment. At this point, it is still a question of which predictors, except the risk of getting infected, are responsible for shortages of blood supplies. The current study proposed that pandemic fatigue was the only significant predictor as an answer to this question.

\section{Study Limitations and Future Implications}

Several limitations may be voiced relating to the present research. First of all, the statements measuring the study variables were adopted from the literature and were translated into Turkish. Therefore, the interpretation of the original items may not have been comprehended easily by the subjects. Despite having expert assistance during the translation process, such a risk may likely arise. To avoid the risk, the Turkish adaptation of the scales had to be carried out by applying statistical techniques. Also, the independent variables assumed to predict blood donation intentions may not be considered as real drives by the subjects. The reported data led to such findings due to the limited number of selected and controlled motives with which the subjects rated. Therefore, the formation of blood donation attitudes during the pandemic period can be expected to ground on a more complex rather than a simple model. Strictly speaking, the concluded inferences may not be anticipated to fully address the shortage in blood supplies during the Covid-19 crisis.

There may also be some objections regarding the research sample. The data analyzed in the study were collected from Turkish university students who were requested to define their attitudes towards blood donation intentions during the pandemic period. 
Considering the potential donors should not be limited to this age group, the sample is hard to represent a cross-sectional feature. In addition, the relevant items in this study applied in the first days of 2021 coincided with the lockdowns when the participants were away from the university. Considering these young people were being confined in their homes and having a very unpleasant emotional experience together with the running of the research through emotional drives may evolve into a striking handicap for the study. As such, the severity of the risk and psychological pressure perceived by our young subjects during the curfews may have been considerably higher than the other age groups representing the real donor candidates. Therefore, possible effects on emotional pathways caused by pandemic fatigue should be judged within these boundaries.

Although the limitations described above, the results of our study ensure comprehension of the details of blood donation attitudes and the decision-making process during the Covid-19 pandemic. However, it is required to develop this understanding by applying a series of donation variables through various sample groups having stronger representation characteristics. Therefore, further methodological initiatives should be conducted and more predictors should be addressed to reach practical insights to enrich the findings of this study. The concepts of social psychology such as self-efficacy, planned action theory, subjective norm, also message framing approaches in advertising, social responsibility and crisis communication should be reconsidered through Covid-19 pandemic. Hence, these motives may serve as examples of constructs that need to be addressed except emotional processes. The altruistic feelings also need to be given a bracket. In one of the few studies on blood donation (Steele et al., 2008), it was founded that altruistic feelings varied by age groups, that is, as people getting older they reflected higher levels of altruistic behaviors. For this reason, the fact that the research sample felt relatively lower risks of infection during the Covid-19 period, may have been the reason for insignificant findings. Rather, it can be assumed that the instrument scores from older participants who could not leave their homes due to the risk of getting infected but whose altruistic feelings were more intense, would likely shift the course of the research. Finally, as key concepts, PSA-induced identity development and altruistic feelings are always open to any debate. Therefore, it is almost an obligation to compare and test more comprehensive message stimuli through a much more convenient sample. However, exploring these assumptions to further support these findings could be the task for future studies. It is expected that these suggestions will shed light on a more comprehensive and descriptive starting point regarding blood donation attitudes during the Covid-19 period.

\section{References}

Bagozzi, R., \& Moore, D., (1994). "Public Service Advertisements: Emotions and Empathy Guide Prosocial Behavior”, Journal of Marketing, 1(58), p. 56-70.

Bandura, Albert, (1977). "Self-Efficacy: Toward A Unifying Theory Of Behavioral Change", Psychological Review, 2(84), p. 191-215. 
Bandura, Albert, (2010). "Self-Efficacy”, The Corsini Encyclopedia Of Psychology, p. 1-3.

Barnes, C., \& Dyne, L., (2009). “'I'm Tired': Differential Effects Of Physical And Emotional Fatigue On Workload Management Strategies”, Human Relations, 1(62), p. 59-92.

Barreto, Ana Margarida, (2019). "Personal Traits Behind The Intention To Donate Blood”, Media \& Jornalismo, 34(19), p. 193-206.

Batson, C., Turk, C., \& Shaw, L., (1995). "Information Function Of Empathic Emotion: Learning That We Value The Other's Welfare", Journal of Personality and Social Psychology, 2(68), p. 300-313.

Beerli-Palacio, A., \& Martín-Santana, J., (2015). “How To Increase Blood Donation By Social Marketing", International Review on Public and Nonprofit Marketing, 3(12), p. 253-266.

Biddle, N., Edwards, B., Gray, M., \& Sollis, K. (2020). Tracking Outcomes During The Covid-19 Pandemic - Divergence Within Australia, Retrieved from https://csrm. cass.anu.edu.au/sites/default/files/docs/2020/9/Tracking_wellbeing_outcomes_during_ the_Covid-19, Date of Access: 19 December 2020

Clowes, R., \& Masser, B. M., (2012). "Right Here, Right Now: The Impact Of The Blood Donation Context On Anxiety, Attitudes, Subjective Norms, Self $\square$ Efficacy, And Intention To Donate Blood", Transfusion, 7(52), p. 1560-1565.

Cohen, Jonathan, (2001). "Defining Identification: A Theoretical Look At The Identification Of Audiences With Media Characters", Mass Communication \& Society, (4), p. 245-264.

Crocker, J., Canevello, A., \& Brown, A. A., (2017). "Social Motivation: Costs And Benefits Of Selfishness And Otherishness", Annual Review of PsychoAnnual Review of Psychology, (68), p. 299-325.

Cropanzano, R., Rupp, D. E., \& Byrne, Z. S., (2003). "The Relationship Of Emotional Exhaustion To Work Attitudes, Job Performance, And Organizational Citizenship Behaviors", Journal of Applied Psychology, (88), p. 160-169.

Dovidio, J., \& Penner, L., (2003). "Helping and Altruism", J. Fletcher, \& M. S. Clark (eds.), Interpersonal Processes, New York: Interpersonal Processes, p. 162-196.

Duncan, L. A., Schaller, M., \& Park, J. H., (2009). "Perceived Vulnerability To Disease: Development And Validation Of A 15-Item Self-Report Instrument", Personality and Individual Differences, 6(47), p. 541-546.

Einolf, Christopher, (2008). "Empathic Concern And Prosocial Behaviors: A Test Of Experimental Results Using Survey Data", Social Science Research, 4(37), p. 12671279. 
Elia, F., \& Vallelonga, F., (2020). "Pandemic Fatigue Or Something Worse?", Recenti Progressi in Medicina, 12(111), p. 788-789.

Epel, E., \& Fromer, E., (2020). "Emotional Well-Being and Coping During Covid-19", Retrieved from UCSF Department of Psychiatry and Behavioral Sciences: https://psychiatry.ucsf.edu/copingresources/covid19. Date of Access: 09.03.2021

Escalas, Jennifer Edson, (2004). "Imagine Yourself In The Product: Mental Simulation, Narrative Transportation, And Persuasion", Journal of Advertising, 2(33), p. $37-48$.

Evans, R., \& Ferguson, E., (2014). "Defining And Measuring Blood Donor Altruism: A Theoretical Approach From Biology, Economics And Psychology", Vox Sanguinis, 2(106), p. 118-126.

Feng, Y., Zong, M., Yang, Z., Gu, W., \& Dong, D., (2020). "When Altruists Cannot Help: The Influence Of Altruism On The Mental Health Of University Students During The Covid-19 Pandemic", Globalization and Health, 1(16), p. 1-8.

Fornell, C., \& Larcker, D., (1981). "Structural Equation Models With Unobservable Variables And Measurement Error: Algebra And Statistics", Journal of Marketing Research, (19), p. 39-50.

Franzen, A., Mader, S., \& Winter, F., (2018). "Contagious Yawning, Empathy, And Their Relation To Prosocial Behavior", Journal of Experimental Psychology, 12(147), p. $2-10$.

Giles, M., McClenahan, C., Cairnt, E., \& Malle, J., (2004). “An Application Of The Theory Of Planned Behaviour To Blood Donation: The Importance Of Self-Efficacy", Health Education Research, 4(19), p. 380-391.

Gill, T., \& Boylan, S., (2012). "Public Health Messages: Why Are They Ineffective And What Can Be Done?", Current Obesity Reports, 1(1), p. 50-58.

Gonzales-Olmo, M., Ortega-Martinez, A., Delgado-Ramos, B., Romero, B., \& Carillo-Diaz, M., (2020). "Perceived Vulnerability To Coronavirus Infection : Impact On Dental Practice", Community Dental Health, (34), p. 1-9.

Green, M., Brock, T., \& Kaufman, G., (2004). "Understanding Media Enjoyment: The Role Of Transportation Into Narrative Worlds", Communication Theory (14), p. 311327.

Hair, J., Anderson, R., Tatham, R., \& Black, W., (1999). Multivariate Data Analysis With Readings, London: Macmillian.

Harrington, M., Sweeney, M., Bailie, K., Morris, K., Kennedy, A., Boilson, A., et al., (2007). “What Would Encourage Blood Donation In Ireland?", Vox Sanguinis, 4(92), p. 361-367. 
Hayes, Andrew, (2013). Introduction to Mediation, Moderation, and Conditional Process Analysis: A Regression-Based Approach, New York: Giilford Press.

Hayes, A., Montoya, A., \& Rockwood, N., (2017). “The Analysis Of Mechanisms And Their Contingencies: Process Versus Structural Equation Modeling", Australasian Marketing Journal, 1(25), p. 76-81.

Healy, Kieran, (2000). "Embedded Altruism: Blood Collection Regimes And The European Union's Donor Population", American Journal of Sociology, 6(105), p. 16331657.

Hefner, D., Klimmt, C., \& Vorderer, P., (2007). "Identification With The Player Character As Determinant Of Video Game Enjoyment", International Conference on Entertainment Computing, Shanghai: Springer, p. 39-48.

Hoeken, H., \& Sinkeldam, J., (2014). "The Role Of Identification And Perception Of Just Outcome In Evoking Emotions In Narrative Persuasion”, Journal of Communication, (64), p. 935-955.

Igartua , J., \& Marcos-Ramos, M., (2015). "Influence Of Character Type And Narrative Setting On Character Desing For Fictional Television Series", Communication \& Society, 1(2), p. 63-78.

Igartua, Juan-José, (2010). "Identification With Characters And Narrative Persuasion Through Fictional Feature Films”, Communications, (35), p. 347-373.

Jolliffe, D., \& Farrington, D., (2006). "Development And Validation Of The Basic Empathy Scale”, Journal of Adolescence, (29), p. 589-611.

Karacan, E., Cengiz, G., Aktan, Z., Ayli, M., \& Palabıyıkoğlu, R., (2013). "Blood Donors And Factors Impacting The Blood Donation Decision: Motives For Donating Blood In Turkish Sample”, Transfusion and Apheresis Science, 3(49), p. 468-473.

Kim, H., Bigman, C., Leader, A., Lerman, C., \& Cappella, J., (2012). "Narrative Health Communication And Behavior Change: The Influence Of Exemplars In The News On Intention To Quit Smoking”, Journal of Communication, 3(62), p. 473-492.

Kinnick, K., Krugman, D., \& Cameron, G., (1996). "Compassion Fatigue: Communication And Burnout Toward Social Problems", Journalism and Mass Communication Quaterly, 3(73), p. 687-707.

Kızılay (2020), Türk Kızılay'dan Acil Kan İhtiyacı Çağrısı. Retrieved from Kızılay Kurumsal Haberler: https://www.kizilay.org.tr/Haber/KurumsalHaberDetay/5116, Date of Access: 13.04.2021

Lay, L., \& Hoppmann, C.A., (2015). Altruism And Prosocial Behavior, Encyclopedia of Geropsychology, New York: Springer.

Lee, H., Fawcett, J., \& DeMarco, R., (2016). "Storytelling/Narrative Theory To Address Health Communication With Minority Populations", Applied Nursing Research, (30), p. 58-60. 
Lee, R., \& Ashforth, B., (1996). “A Meta-Analytic Examination Of The Correlates Of The Three Dimensions Of Job Burnout", Journal of Applied Psychology (83), p. 123133.

Lemmens, K., Abraham, C., Ruiter, R., Veldhuizen, J., Dehing, C., Bos, E., et al., (2009). "Modelling Antecedents Of Blood Donation Motivation Among Non-Donors Of Varying Age And Education”, British Journal of Psychology, 1(100), p. 71-90.

Leung, J., \& Lee, C., (2020). “Impact OfThe Covid $\square$ 19-A Regional Blood Centre’s Perspective”, ISBT Science Series, 4(15), p. 362-364.

Lilleholt, L., Zettler, I., Betsch, C., \& Böhm, R., (2020). "Correlates And Outcomes Of Pandemic Fatigue", PsyArXiv Preprints, p. 1-36.

Lundgren, R., \& McMakin, A., (2013), Risk Communication. A Handbook for Communicating Environmental, Safety, and Health Risks, London: John Wiley \& Sons, Inc.

Maddux, J., \& Gosselin, J., (2012), Self-Efficacy, New York: The Guilford Press.

Martín-Santana, J., Reinares-Lara, E., \& Reinaras-Lara, P., (2018), "Using Radio Advertising To Promote Blood Donation", Journal of Nonprofit and Public Sector Marketing, 1(30), p. 52-73.

Maslach, C., (1982), Burnout: The Cost Of Caring. London: Prentice-Hall.

Masser, B. M., Hyde, M. K., \& Ferguson, E., (2020). "Exploring Predictors Of Australian Community Members' Blood Donation Intentions And Blood DonationRelated Behavior During The Covid-19 Pandemic", Transfusion, (8), p. 2907-2917.

Miah, Muhammed, (2020). "Study Of Blood Donation Campaign Communication Methods And Attributes Of Donors: A Data Analytics Approach", International Journal of Healthcare Management, 1(1), p. 1-11.

Morgan, Christian, (2020). Feeling tired during the Covid-19 pandemic?, Retrieved from ABC News.: https://www.abc.net.au/news/2020-09-09/fatigue-during-covid-19pandemic-how-to-lift-energy-motivation/12640002, Date of Access: 21.02.2021

Morgul, E., Bener, A., Atak, M., Akyel, S., Aktaş, S., Bhugra, D., et al., (2020). "Covid-19 Pandemic And Psychological Fatigue In Turkey", The International Journal of Social Psychiatry (7), p. 1-8.

Moyer-Gusé, Emily, (2008). "Toward A Theory Of Entertainment Persuasion: Explaining The Persuasive Effects Of Entertainment-Education Messages", Communication Theory, 3(18), p. 407-425.

Murphy, S. T., Frank, L. B., Chatterjee, J. S., \& Baezconde-Garbanati, L., (2013). "Narrative Versus Nonnarrative: The Role Of Identification, Transportation, And Emotion In Reducing Health Disparities", Journal of Communication, 1(63), p. 116-137. 
Murphy, W., \& Mcsweeney, E., (2009). “The Role OfAltruistic Behavior, Empathetic Concern, And Social Responsibility Motivation In Blood Donation Behavior", Practical Transfusion Medicine, 2(48), p. 190-199.

Neil, J. M., Gough, A., Kee, F., George, T., Pufahl, J., \& Krieger, J. L., (2019). "The Influence Of Patient Identification And Narrative Tansportation On Intentions To Participate In Cancer Research", Journal of Cancer Education, 4(34), p. 725-734.

Özgüven, İsmihan, (2020). Ease Of Transportation By Private Vehicle For Blood Donors, Retrieved from Anadolu Ajans1: https://www.aa.com.tr/tr/yasam/kanbagiscilarina-ozel-aracla-ulasim-kolayligi/1866170\#, Date of Access: 10.01.2021

Raghuwanshi, B., Pehlajani, N. K., \& Sinha, M. K., (2016). "Voluntary blood donation among students - a cross-sectional study on knowledge and practice vs. Attitude", Journal of Clinical and Diagnostic Research, 10(10), p. 18-22.

Rushton, J. P., Chrisjohn, R. D., \& Fekken, G. C., (1981). “The Altruistic Personality And The Self-Report Altruism Scale", Personality and Individual Differences, 4(2), p. 293-302.

Santos, Reynaldo, (1999). “Cronbach's Alpha: A Tool For Assessing The Reliability Of Scales", Journal of Extension, 2(37), p. 1-5.

Sojka, B. N. \& Sojka, P., (2008). “The Blood Donation Experience: Self-Reported Motives And Obstacles For Donating Blood”, Vox Sanguinis, 1(94), p. 56-63.

Steele, W. R., Schreiber, G. B., Guiltinan, A., Nass, C., Glynn, S. A., Wright, D. J., et al., (2008). "The Role Of Altruistic Behavior, Empathetic Concern, And Social Responsibility Motivation In Blood Donation Behavior", Transfusion, 1(48), p. 43-54.

Taylor, S. E., \& Schneider, S. K., (1989). "Coping And The Simulation Of Events", Social Cognition, 2(7), p. 174-194.

Van Der Pligt, J., (1998). "Perceived Risk And Vulnerability As Predictors Of Precautionary Behaviour", British Journal of Health Psychology, 1(3), p. 1-14.

WHO, (2020). Guidance On Maintaining A Safe And Adequate Blood Supply During The Coronavirus Disease 2019 (Covid-19) Pandemic And On The Collection Of Covid-19 Convalescent Plasma, https://apps.who.int/iris/handle/10665/333182. Date of Access: 02.02.2021.

WHO, (2020). Pandemic Fatigue - Reinvigorating The Public To Prevent Covid-19. Policy Framework For Supporting Pandemic Prevention And Management, https://apps. who.int/iris/handle/10665/337574. Date of Access: 02.02.2021

Wildman, J., \& Hollingsworth, B., (2009). "Blood Donation And The Nature Of Altruism", Journal of Health Economics, 3(28), p. 492-503.

Wright, T. A., \& Cropanzano, R., (1998). "Emotional Exhaustion As A Predictor Of Job Performance And Voluntary”, Journal of Applied Psychology, (83), p. 486-493. 
Yamada, Y., Xu, H., \& Sasaki, K., (2020). “A Dataset For The Perceived Vulnerability To Disease Scale In Japan Before The Spread Of Covid-19”, Research, (9), p. 1-10.

Zillmann, Dolf, (1991). "Empathy: Affect From Bearing Witness To The Emotions Of Others", J. B. Zillmann (ed.), Responding To The Screen: Reception And Reaction Processes, New York: Routledge, p. 135-168.

Zillmann, Dolf, (1999). "Exemplification Theory: Judging The Whole By Some Of Its Parts”, Media Psychology, 1(1), p. 69-94.

Destekleyen Kurum/Kuruluşlar: Herhangi bir kurum/kuruluştan destek alınmamıştır.

Çıkar Çatışması: Herhangi bir çıkar çatışması bulunmamaktadır. 